(6)

\section{OPEN ACCESS}

${ }^{1}$ UK Centre for Tobacco Control Studies/Division of Epidemiology and Public Health, School of Community Health Sciences, University of Nottingham, City Hospital, Nottingham, UK

${ }^{2}$ UK Centre for Tobacco Control Studies/Addictions Department, Institute of Psychiatry, King's College London, London, SE58AF, UK

\section{Correspondence to}

Dr Ailsa Lyons, Division of Epidemiology and Public Health, The University of Nottingham, Clinical Sciences Building, City Hospital, Hucknall Road, Nottingham, NG5 1PB, UK;

Ailsa.Lyons@nottingham.ac.uk.

Received 25 June 2012 Revised 24 January 2013 Accepted 29 January 2013 Published Online First 11 March 2013

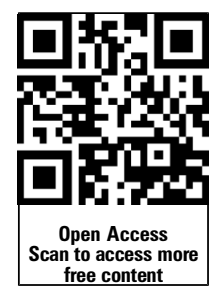

To cite: Lyons A, McNeill A, Britton J. Tob Control 2014;23:257-263.

\title{
Tobacco imagery on prime time UK television
}

\author{
Ailsa Lyons, ${ }^{1}$ Ann McNeill, ${ }^{2}$ John Britton ${ }^{1}$
}

\begin{abstract}
Background Smoking in films is a common and well documented cause of youth smoking experimentation and uptake and hence a significant health hazard. The extent of exposure of young people to tobacco imagery in television programming has to date been far less investigated. We have therefore measured the extent to which tobacco content occurs in prime time UK television, and estimated exposure of UK youth. Methods The occurrence of tobacco, categorised as actual tobacco use, implied tobacco use, tobacco paraphernalia, other reference to tobacco, tobacco brand appearances or any of these, occurring in all prime time broadcasting on the five most popularly viewed UK television stations during 3 separate weeks in 2010 were measured by 1-minute interval coding. Youth exposure to tobacco content in the UK was estimated using media viewing figures.
\end{abstract}

Findings Actual tobacco use, predominantly cigarette smoking, occurred in 73 of $613(12 \%)$ programmes, particularly in feature films and reality TV. Brand appearances were rare, occurring in only 18 programmes, of which 12 were news or other factual genres, and 6 were episodes of the same British soap opera. Tobacco occurred with similar frequency before as after 21:00, the UK watershed for programmes suitable for youth. The estimated number of incidences of exposure of the audience aged less than 18 years for any tobacco, actual tobacco use and tobacco branding were 59 million, 16 million and 3 million, respectively on average per week.

Conclusions Television programming is a source of significant exposure of youth to tobacco imagery, before and after the watershed. Tobacco branding is particularly common in Coronation Street, a soap opera popular among youth audiences. More stringent controls on tobacco in prime time television therefore have the potential to reduce the uptake of youth smoking in the UK.

\section{INTRODUCTION}

Smoking and other tobacco content are common in films marketed to children and young people in the $\mathrm{UK}^{1}$ and elsewhere, ${ }^{2-4}$ and as a recognised cause of experimentation and uptake of smoking among youth $^{5-8}$ represent a significant public health hazard. However, since an estimated 27 million British homes have a television, ${ }^{9}$ and young people aged between 6 years and 17 years in Britain report that they watch television for an average of $2.5 \mathrm{~h}$ each day, ${ }^{10}$ with $77 \%$ of film viewing occurring through television airing, ${ }^{11}$ television has the potential to reach far larger audiences than films alone. Evidence from other countries indicates that tobacco content is common in popular television programmes, ${ }^{12-17}$ occurring in around $40 \%$ of US $^{14}$ and $50 \%$ of German television ${ }^{15}$ programmes according to recent reports. However the only recent study of UK television content is an analysis of the 10 most popular programmes among 1015 -year-olds, carried out in 2005, which reported low levels of smoking content. ${ }^{18}$ The extent to which children are exposed to tobacco content across the full range of programmes broadcast on television, including feature films, is unknown.

Tobacco advertising, promotion and sponsorship, including all television advertising and paid product placement, is now prohibited in the UK by the 2002 Tobacco Advertising and Promotion Act. ${ }^{19}$ However, tobacco imagery included in television programmes for artistic or editorial purposes is exempt from the Act. Television broadcasting content in the UK is regulated by Ofcom, ${ }^{20}$ an independent regulator which under the provisions of the 2003 Communications $\mathrm{Act}^{21}$ publishes standards for the content of television programmes. ${ }^{22}$ Ofcom defines a 21:00 watershed before which programmes should not be broadcast if unsuitable for children (those aged under 15 years), but in relation to smoking content advises only that before the watershed smoking should be 'editorially justified'. ${ }^{23}$ To determine the extent to which children are exposed to smoking and other tobacco content in a representative sample of UK television programming we have therefore characterised the content of all programmes broadcast on the five national UK free-to-air channels during the peak viewing hours of 18:00-22:00 during three separate weeks in 2010, and used independent audience viewing figures to estimate youth exposure to the tobacco content.

\section{METHODS}

At the time of the study there were five national free-to-air channels available for viewing without a cable or satellite connection or subscription in the UK (BBC1, BBC2, ITV1, Channel 4, Channel 5), and these are the most frequently viewed UK channels. ${ }^{24}$ Three of these (ITV1, Channel 4 and Channel 5) are commercial stations which broadcast commercial advertising; $B B C 1$ and $B B C 2$ are public service channels with no commercial advertising.

For 7 days from Monday to Sunday on three occasions 4 weeks apart (19th-25th April; 17th23rd May; and 14th-20th June 2010) we recorded all material broadcast by these five channels between 18:00 and 22:00, thus capturing $3 \mathrm{~h}$ before and 1 hour after the Ofcom 21:00 watershed. ${ }^{23}$ Broadcasts were then analysed and coded in 1-minute intervals, recording tobacco appearances in any of the following categories:

Actual tobacco use: use of tobacco onscreen by any character, coded as cigarette, cigar, pipe or other (such as water pipe or chewing tobacco). 
Implied tobacco use: any inferred tobacco use occurring without actual use onscreen (eg, a comment about going for a cigarette or a smoky atmosphere), and coded as verbal or non-verbal.

Tobacco paraphernalia: the presence onscreen of tobacco or tobacco related materials, coded by the type of appearance (including cigarette or other tobacco pack, matches, lighter, ashtray, no smoking or smoking area signs).

Other references to tobacco: any reference to tobacco that did not involve actual or implied use, (eg, a news report of a new smoking cessation service), coded as being either verbal or non-verbal

Tobacco brand appearance: the presence of clear and unambiguous tobacco branding, and including cigarette or other tobacco packs, secondary advertising (advertisements appearing within other programmes) and branded merchandising Any tobacco content: the occurrence of any of the above.

Interval recording methods have previously been shown to be a sensitive means of detecting relative changes in behaviour levels and previously used in studies exploring tobacco in films ${ }^{3} 2526$ and television. ${ }^{27} 28$ Tobacco appearances were recorded as having occurred if observed onscreen once or more in any 1-minute coding period. Where multiple appearances of the same category in the same 1-minute interval occurred, this was considered a single event. Appearances that crossed a transition from one 1-minute interval to the next were recorded as having occurred in two separate intervals, and thus as two separate appearances. However, if appearances were in different coding categories (eg, if actual tobacco use and paraphernalia occurred in the same interval) then these were recorded as two separate instances. Since changes from one programme to the next, or breaks in a programme for advertising frequently did not occur at the end of a 1-minute interval, we coded partminutes immediately before programme changes. For each minute that crossed over the transition from advertisements to programmes, and vice versa, half the minute was considered advertising, and half as programming, and recorded as partminutes. Although the BBC channels showed no commercial advertising they did broadcast programme trailers in the breaks between programmes. This also occurred on the commercial channels, when they were often mixed with commercial advertising. We therefore coded advertisements and trailers together. We also categorised the genre of the programme (comedy, drama, soap opera, news, game show, feature film, chat show, sport, party political broadcast, documentary, reality TV, sci-fi/ fantasy), as identified from the programme announcement, the Internet Movie Database, the channel's webpage or the researcher's discretion, and noted whether any part of the programme was broadcast before or after the 21:00 watershed.

Live audience viewing figures for the 18:00-22:00 study period in the under 18-year-old age group collected by the Broadcasters' Audience Response Board ${ }^{29}$ were obtained from Attentional, ${ }^{30}$ a commercial media consultancy firm. Data excluded programmes that began before 18:00, news programmes (because of regional variation) and advertisements or trailers.

Comparisons of tobacco content between programme genres and channels were made using multiple logistic regressions which allowed for clustering within each 4-h recorded interval. The $p$ values for the effect of channel and genre were obtained using the Wald test as the likelihood ratio test was inappropriate due to the use of robust variance estimates to allow for clustering. These Wald tests are still testing whether there is a difference overall between channels or genres.
To estimate the total amount of exposure to tobacco content for the under 18-year-old audience, we first multiplied the number of intervals in each programme that contained at least some tobacco content (any tobacco, actual use and branded tobacco appearances) by the estimated number of viewers of that programme (ie, total number of exposures per programme). Then, we summed the total number of exposures per programme to give an overall total number of exposures to tobacco content among British youth.

\section{RESULTS}

The $420 \mathrm{~h}$ of recorded broadcasting comprised 613 programmes and 1121 advertisements/trailers, and included 25210 part or full 1-minute intervals, of which 21996 were from programmes and 3214 from advertisements/trailers. Channel 5 broadcast a total of 165 different programmes; BBC1 120, BBC2 116, Channel 4109 and ITV1 103. Documentaries (161), news programmes (139) and soap operas (72) were the most frequent programme genres. Documentaries also occupied the greatest amount of broadcasting time $(6935 \mathrm{~min})$, followed by news (2862 $\mathrm{min})$, drama (2250 $\mathrm{min})$ and sport (2169 $\mathrm{min})$.

\section{Any tobacco content}

There were 731 intervals (2.9\% of total) containing any tobacco appearances, and for the most part comprised tobacco paraphernalia (figure 1). This proportion was highest on ITV1 (3.6\%) and lowest on Channel 5 (2.4\%), but not significantly so after allowing for clustering within each channel (Wald $\chi \mathrm{i}^{2}=4.36$, $\mathrm{p}=0.36)$. Of the 613 programmes broadcast, $210(34 \%)$ contained any tobacco, occurring in 699 (3.2\%) of 1-minute intervals in programmes (range $2.3 \%$ to $4.5 \%$ between channels). Tobacco content differed significantly between genres, occurring at least once in more than half of all reality TV (67\%), feature films (64\%) and comedy (52\%) programmes (soap opera (49\%); drama (48\%); chat show (37\%); documents $(37 \%)$; news $(22 \%)$; sport $(21 \%)$; game show $(20 \%)$; party political broadcast (5\%); Sci-fi/fantasy (0\%)). When channel and genre were included in a logistic regression model with allowance for clustering, there was still no significant difference between channels (Wald $\chi^{2}=7.31$, p value $=0.12$ ) but the difference between genres remained so (Wald $\chi^{2}=77.10, p<0.05$ ). News, game shows, sports and documentaries were significantly less likely to include any tobacco content than comedy (baseline). Of 1,121

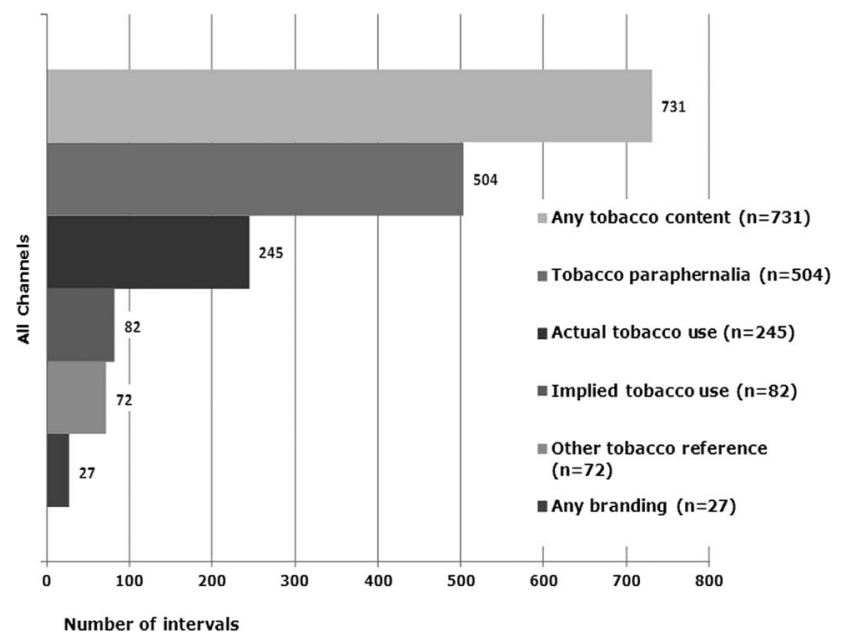

Figure 1 Number of 1-minute intervals that contained any tobacco by coded category. 
advertisements/trailers analysed, 29 (2.6\%) contained any tobacco, occurring in 32 of 3214 1-minute intervals of advertisements/trailers. With the exception of advertisements for smoking cessation products this occurred almost entirely in programme trailers. The $75 \%$ of hours of programming in our sample broadcast before the 21:00 watershed contained $69 \%$ of the observed tobacco appearances.

\section{Actual tobacco use}

Actual tobacco use appearances occurred in $245(1 \%)$ of all intervals, in $73(12 \%)$ programmes and 7 (0.7\%) advertisements/trailers, all of which were trailers on BBC1 or BBC2. Most actual tobacco use appearances were of cigarette smoking (183 intervals; 75\%), followed by pipe (19\%) and cigar smoking (8\%). Actual tobacco use occurred in 9 of the 12 programme genres (figure 2), and at least once in more than half of all feature films and reality TV. The majority of actual tobacco use appearances (60\%) were broadcast before 21:00. Of the 13 feature films that contained actual tobacco use, 9 were broadcast on one channel (Channel 5) and 10 were broadcast, in whole or in part, before 21:00. All of the films shown had been classified by the British Board of Film Classification as suitable for viewing by children, and six of them with no age restriction (classified PG or U). When channel and genre were included in a logistic regression model, feature films were significantly more likely and soap opera, news, sport, chat show, and documentary genres less likely to include actual tobacco use in comparison with comedy (baseline); there was no significant difference between channels.

\section{Implied tobacco use, tobacco paraphernalia and other tobacco references}

At least one appearance of implied tobacco use, tobacco paraphernalia or other reference to tobacco occurred in $618(2.5 \%)$ intervals. Tobacco paraphernalia occurred in 504 intervals in 204 separate broadcasts (programmes and advertisement/trailer breaks combined), and predominantly comprised no-smoking signs and/or symbols (52\%), followed by cigarettes, cigars, pipes, tobacco packets (23\%), ashtrays (14\%), lighters or matches (9\%) and other (1\%). Other tobacco paraphernalia appearances comprised Nicorette inhalators, a cigarette vending machine, a picture of a pipe and a metal cigarette carrying case. Implied tobacco use occurred in 82 intervals $(0.3 \%)$ and was usually non-verbal (56 intervals, 68\%). Other references to tobacco occurred in 71 intervals in 33 broadcasts, most of them (97\%) verbal.

\section{Tobacco brand appearances}

There were 66 tobacco brand appearances, occurring in 27 intervals in 18 programmes. The frequency of brand appearances differed significantly between channels (Wald $\chi^{2}=11.54$, $\mathrm{p}=0.02$ ), being most frequent on BBC1 and ITV1. Although some of these brand appearances occurred in historical footage, the most common source was point-of-sale tobacco displays, sometimes in news reporting, but predominantly in soap operas or other fiction (table 1). When comparing genres in which at least one 1-minute interval of tobacco brand appearance occurred, there was a significant difference before (Wald $\chi^{2}=46.74, p=0.001$ ) and after (Wald $\chi^{2}=15.14, p=0.02$ ) adjustment for differences in channels. The programme with the most brand occurrences was an ITV1 soap opera, Coronation Street. Almost all brand appearances (97\%) occurred before 21:00. The most common brands appearing were Silk Cut and Mayfair, both of which are Gallaher Group (now Japan Tobacco International) products.

\section{Estimated exposure}

In the 520 programmes for which viewing data were available, there were 184 programmes that included 652 intervals containing any tobacco, 65 containing 219 intervals of actual tobacco use and 15 containing 25 intervals of tobacco brand appearance. All of these programmes were watched by youth audiences, averaging 265000 and ranging from 4600 to 1968000 . The estimated number of youth viewers watching each programme, categorised by the number of tobacco intervals (any tobacco, actual tobacco use and tobacco brand appearance) contained is shown in a scatter plot in figure 3 . These content and audience data translated into an average total number of instances of exposure of 59 million for any tobacco, 16 million for actual tobacco use and 3 million for tobacco brand appearances per week.

\section{DISCUSSION}

This study demonstrates that although tobacco occurred much less frequently on television than has previously been documented for films, ${ }^{1}$ tobacco content remains present in a third of all
Figure 2 The proportion of each genre that contained, and did not contain actual tobacco use $(n=613)$.

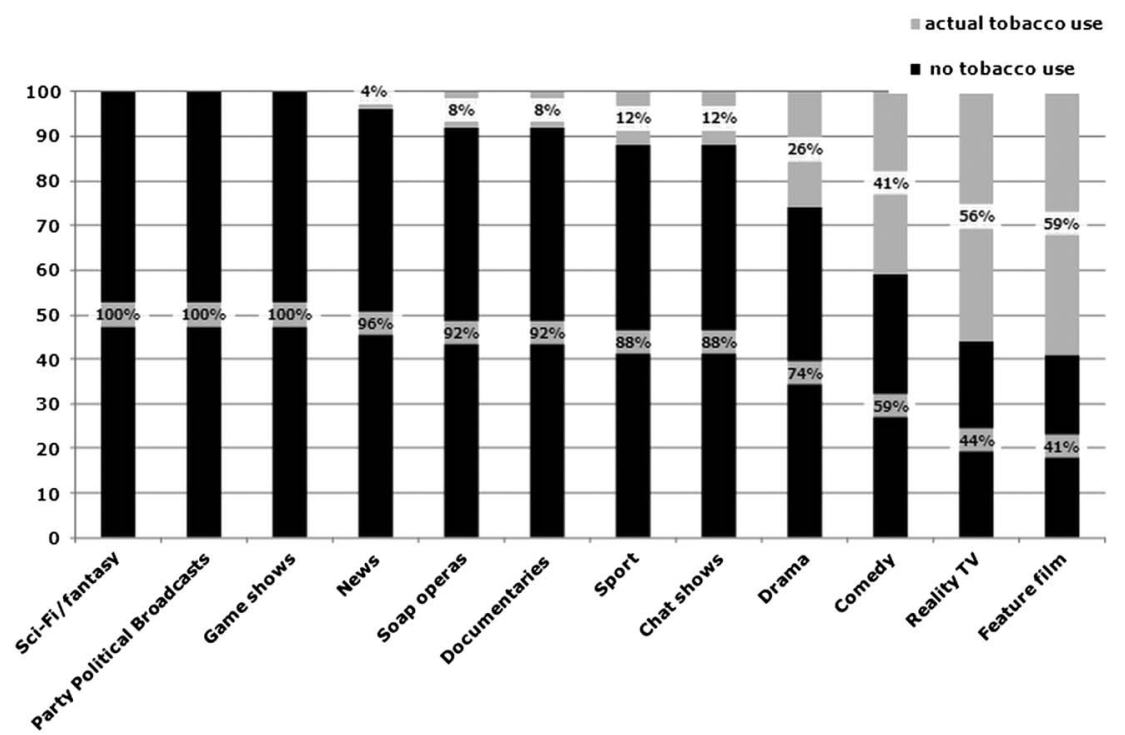




\begin{tabular}{|c|c|c|c|c|c|c|c|c|}
\hline Genre & Programme & $\begin{array}{l}\text { Broadcast } \\
\text { time* }\end{array}$ & $\begin{array}{l}\text { Pre/post } \\
\text { watershed }\end{array}$ & Intervals & $\begin{array}{l}\text { No. of } \\
\text { brands }\end{array}$ & Brands & $\begin{array}{l}\text { Type of brand } \\
\text { appearance }\end{array}$ & Description \\
\hline \multicolumn{9}{|l|}{ BBC1 } \\
\hline Chat show & The One Show & $18: 58-19: 27$ & Pre & 3 & 12 & $\begin{array}{l}\text { Mayfair (2), Superkings (2); Silk Cut } \\
\text { (2); Lambert and Butler (2); Benson } \\
\text { and Hedges (2); Hamlet (1); Berkley (1) }\end{array}$ & Cigarette packets & Branded cigarette packets visible \\
\hline Game show & $\begin{array}{l}\text { A Question of } \\
\text { sport }\end{array}$ & 19:29-19:58 & Pre & 1 & 2 & Rothmans (1), Marlboro (1) & $\begin{array}{l}\text { Advertisement and } \\
\text { sponsorship }\end{array}$ & $\begin{array}{l}\text { Clip of Formula One racing-Large Marlboro adverts, and } \\
\text { Rothmans branded car }\end{array}$ \\
\hline News & BBC News & 18:00-18:57 & Pre & 1 & 2 & Benson and Hedges (1), Mayfair (1) & Cigarette packets & Branded cigarette packets visible \\
\hline Soap opera & Eastenders & 19:29-19:58 & Pre & 1 & 6 & $\begin{array}{l}\text { Richmond (1), Rizla (1), Regal (1), } \\
\text { Superkings (1), John player (1), } \\
\text { Lambert and Butler (1) }\end{array}$ & Cigarette packets & $\begin{array}{l}\text { Branded cigarette packets visible (Also, Niquitin CQ and Nicorette } \\
\text { visible) }\end{array}$ \\
\hline \multicolumn{9}{|l|}{ BBC2 } \\
\hline Documentary & $\begin{array}{l}\text { Mary Queen of } \\
\text { Shops }\end{array}$ & 19:03-20:02 & Pre & 1 & 3 & $\begin{array}{l}\text { Marlboro green (1); Marlboro gold (1); } \\
\text { Rizla (1) }\end{array}$ & Cigarette packets & Branded cigarette packets visible \\
\hline Drama & Money & $21: 02-22: 00$ & Post & 1 & 1 & Winston (1) & Cigarette packet & Branded tobacco packet on table \\
\hline \multicolumn{9}{|l|}{ ITV1 } \\
\hline Soap opera & $\begin{array}{l}\text { Coronation } \\
\text { Street }\end{array}$ & $20: 30-20: 57$ & Pre & 2 & 8 & $\begin{array}{l}\text { Silk cut (2); Superkings (1); Mayfair (2); } \\
\text { Regal (1); Benson and Hedges (1); } \\
\text { Lambert and Butler (1) }\end{array}$ & Cigarette packets & Branded cigarette packets visible \\
\hline Soap opera & $\begin{array}{l}\text { Coronation } \\
\text { Street }\end{array}$ & 19:31-19:58 & Pre & 1 & 1 & Hamlet (1) & Cigar box & Cigar tin visible behind the bar in the Rovers Return bar \\
\hline Soap opera & $\begin{array}{l}\text { Coronation } \\
\text { Street }\end{array}$ & 20:29-20:57 & Pre & 1 & 3 & Silk Cut (1); Regal (1); Mayfair (1) & Cigarette packets & Branded cigarette packets visible \\
\hline Soap opera & $\begin{array}{l}\text { Coronation } \\
\text { Street }\end{array}$ & 19:32-19:59 & Pre & 1 & 2 & Lambert and Butler (1); Mayfair (1) & Cigarette packets & Branded cigarette packets visible \\
\hline Soap opera & $\begin{array}{l}\text { Coronation } \\
\text { Street }\end{array}$ & $20: 30-20: 58$ & Pre & 5 & 11 & Silk Cut (5); Mayfair (5); Regal (1) & Cigarette packets & Branded cigarette packets visible \\
\hline Soap opera & $\begin{array}{l}\text { Coronation } \\
\text { Street }\end{array}$ & $20: 28-20: 56$ & Pre & 1 & 2 & Hamlet cigars (1); Silk Cut Purple (1) & $\begin{array}{l}\text { Cigarette packet } \\
\text { and cigar tin }\end{array}$ & Branded cigarette packets visible \\
\hline News & ITV News & 18:00-18:57 & Pre & 1 & 3 & $\begin{array}{l}\text { Mayfair (1); Silk Cut (1); Benson and } \\
\text { Hedges (1) }\end{array}$ & Cigarette packets & Branded cigarette packets visible \\
\hline \multicolumn{9}{|l|}{ Channel4 } \\
\hline Reality TV & Big Brother & $21: 02-22: 00$ & Post & 1 & 1 & Golden Virginia (1) & Tobacco packets & Branded tobacco packets visible \\
\hline \multicolumn{9}{|l|}{ Channel5 } \\
\hline Documentary & $\begin{array}{l}\text { Britain's } \\
\text { Greatest } \\
\text { Machines }\end{array}$ & $20: 02-20: 59$ & Pre & 2 & 5 & John Player (5) & $\begin{array}{l}\text { Adverts and } \\
\text { sponsorship }\end{array}$ & $\begin{array}{l}\text { Clip of } 80 \text { 's motor racing showing track side advert for John } \\
\text { Player, also John Player Special branded motor racing cars }\end{array}$ \\
\hline Chat show & $\begin{array}{l}\text { Live from } \\
\text { Studio } 5\end{array}$ & $18: 30-19: 26$ & Pre & 2 & 2 & Marlboro (2) & $\begin{array}{l}\text { Branded cigarette } \\
\text { and merchandise }\end{array}$ & $\begin{array}{l}\text { Item on show about methods of stopping smoking, a clip of a } \\
\text { close up of someone lighting a cigarette is shown, the cigarette is } \\
\text { Marlboro branded; close up of an ashtray showing Marlboro } \\
\text { branded cigarettes }\end{array}$ \\
\hline Feature film & Secret Window & $21: 01-22: 00$ & Post & 1 & 1 & $L$ and $M(1)$ & Cigarette packet & $\begin{array}{l}\text { Main character takes a packet of cigarettes out of his desk ( } \mathrm{L} \text { and } \\
\text { M branded) }\end{array}$ \\
\hline News & C5 News & 18:59-19:01 & Pre & 1 & 1 & Marlboro (1) & $\begin{array}{l}\text { Branded } \\
\text { merchandise }\end{array}$ & $\begin{array}{l}\text { News item: about paying people to stop smoking, close up of } \\
\text { Marlboro branded, ashtray visible }\end{array}$ \\
\hline
\end{tabular}


Figure 3 Youth audience for programmes containing tobacco intervals, categorised by the number of intervals per programme.
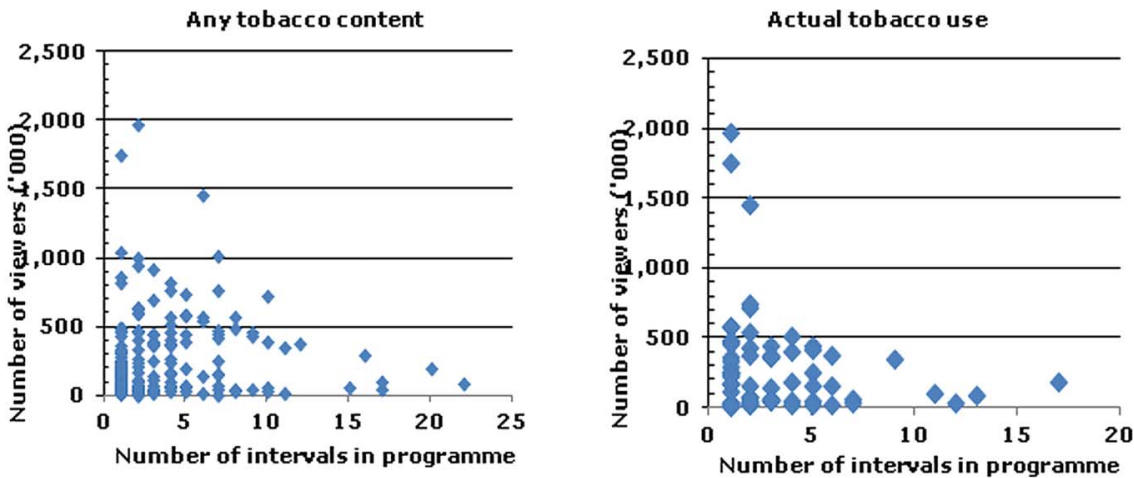

Tobacco brand appearance

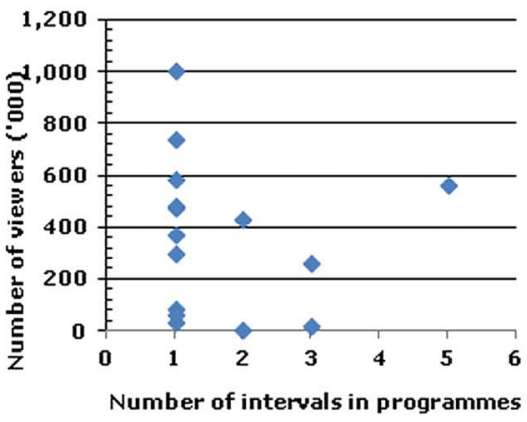

prime time free-to-air television programmes broadcast in the UK. Although much of this imagery comprised paraphernalia including no smoking signs, actual tobacco use occurred in $12 \%$ of programmes, predominantly feature films, reality television and comedy genres. Brand appearances were rare and sometimes occurred in historical footage, but arose predominantly from images of point-of-sale displays broadcast in news and other factual reporting, and in fictional soap opera and other drama. Brand appearances were particularly common in one soap opera, Coronation Street, which is broadcast on five occasions per week by ITV1 and attracted between 6.5 and 10.4 million viewers per episode. ${ }^{31}$ Tobacco appearances were similarly frequent before and after the 21:00 watershed, and were viewed by substantial British youth audiences, generating millions of episodes of exposure to smoking messages and tobacco branding per week.

Relative to feature film analysis, interval coding of television programmes is particularly time consuming because the short duration of programmes and advertisements/trailers demands the use of much shorter intervals for analysis. We used 1-minute intervals, with subdivisions to accommodate programme changes within intervals, and to make the workload manageable elected to code peak-time broadcasting over three 1-week periods. Our sample is therefore susceptible to seasonal influences on television content and news stories, but it is unlikely that this has distorted our findings because the main sources of tobacco content were programme genres that are shown throughout the year. At $420 \mathrm{~h}$ of broadcasting we analysed considerably more material than most other published studies, ${ }^{12} 1432$ including the $140 \mathrm{~h}$ of UK programming analysed by Ofcom in $2005,{ }^{18}$ and since we included all programming during 4 prime time hours each day, our sample is more representative of broadcasting viewed by children and young people in the UK than any other study. The audience viewing figures showed sizeable estimates of youth audiences for each of the programmes included in this study, suggesting significant amounts of youth exposure to the tobacco appearances observed in our coding.

Exposure to tobacco content in films increases experimentation and uptake of smoking among children and young people ${ }^{5-7}$ and there is growing evidence that the same applies for tobacco content on television. Television viewing in general has been shown to be associated with smoking, ${ }^{33} 34$ and also with earlier onset of smoking in adolescence ${ }^{35}$ and increased smoking initiation, ${ }^{36}{ }^{37}$ Although further research would be required to determine if the effects of exposure to tobacco content in television is similar to that of film. Not all of the tobacco we observed was necessarily similarly hazardous, as the impact of tobacco paraphernalia such as no-smoking signage is likely to be very different from actual tobacco use, and indeed some tobacco content arose from smoking cessation promotions. However, actual tobacco use provides a strong behavioural model for young people likely to be as potent in television programmes as in films. Tobacco brand appearances are likely to create and reinforce brand awareness among young viewers. As has been shown both interval categories were widely viewed by young audiences.

We have previously reported high levels of tobacco content in film, including films classified as suitable for viewing by children, ${ }^{1}$ so it is not surprising that these films contribute a significant component of broadcast content when they come to be shown on television. This observation, and the fact that they tend to be shown before the 21:00 watershed, provides further support to calls for films containing smoking to be classified as unsuitable for viewing by children and young people. ${ }^{38-40}$ Other prominent sources of smoking content in our study included reality TV, soap operas, comedy and drama, and although smoking content in programmes shown before the 21:00 watershed is required by Ofcom to be editorially justified, that justification was rarely evident to us. The inclusion of real tobacco brands (as opposed to fictitious brands) in Coronation Street and other fictional programmes appeared particularly 
unnecessary, and of questionable legality given that the 2002 Tobacco Advertising and Promotions Act, ${ }^{19}$ which covers programming content as well as advertisements, prohibits the display of an advertisement 'whose purpose is to promote a tobacco product, or whose effect is to do so. ${ }^{19}$ Ofcom has been aware of the high levels of tobacco in UK soap operas since $2005^{18}$; our findings in comparison with that study ${ }^{18}$ suggest that Coronation Street is the only soap opera that has not appreciably reduced tobacco content since then. Although much of this brand imagery arose from point-of-sale displays which are now scheduled to be prohibited in England (where Coronation Street is set), this change is not scheduled to apply to small retailers, such as those represented in Coronation Street, until 2015.

Our study thus demonstrates that tobacco content, including smoking and tobacco branding, occurs to an appreciable degree in UK television, and in programmes watched by youth audiences, and as such is likely to increase brand awareness and the risk of smoking experimentation and uptake among young children. Although our analysis was limited to UK television it is likely that similar exposures occur elsewhere, and further studies are required to investigate this; however our observations on feature films and to a lesser extent UK programmes such as Coronation Street that are broadcast widely in other countries translate more generally. We suggest that guidelines on tobacco content need to be revised and more carefully enforced if we are to protect children from this hazardous exposure. Therefore we would recommend that future television programming remove gratuitous depictions of tobacco, particularly actual smoking and tobacco branding, from programmes aimed at young people or, in the UK, scheduled before the 21:00 watershed.

\section{Key messages}

- Previous studies have shown that tobacco imagery is common in films watched by children and young people, and that the film classification system used in the UK fails to protect against this exposure.

- This study demonstrates that tobacco imagery also occurs in UK prime time television and is seen by millions of children and young people. It shows that films are a major source of this exposure, but that tobacco imagery also occurs in other genres and particularly in Coronation Street, a soap opera popular among youth audiences, in which tobacco branding is also common. The occurrence of tobacco imagery is equally common before and after the UK's 21:00 watershed for acceptable youth viewing.

- Tobacco content in mainstream television is thus a potentially important source of exposure of children and young people to tobacco brands and smoking behavioural modelling, which should be considered by UK television regulators.

Acknowledgements The authors thank Professor Sarah Lewis for assistance with statistical analysis.

Contributors AL undertook this piece of research as part of her $\mathrm{PhD}$ under supervision of $\mathrm{AM}$ and JB. The initial PhD project outline was written by $\mathrm{AM}$ and JB. The literature review, television recording and coding, data analysis, and drafts of the paper were carried out by $A L$, and supervised by JB and $A M$. AM and JB gave advice on interpretation, made amendments to and gave comments on the paper.

Funding This research was conducted as part of the research undertaken by Ailsa Lyons as part of her PhD. The PhD was funded by The UK Centre for Tobacco
Control Studies is a UKCRC Centre of Public Health Research Excellence. Funding from the British Heart Foundation, Cancer Research UK, the Economic and Social Research Council, the Medical Research Council and the Department of Health.

\section{Competing interests None}

Provenance and peer review Not commissioned; externally peer reviewed.

Data sharing statement The dataset used for this study was compiled by the authors specifically for this study. Free-to-air television broadcasting were recorded and coded for tobacco content, then analysed with the findings reported here. In addition to this data were collected on the alcohol content of the same broadcasting and is in the process of being analysed.

Open Access This is an Open Access article distributed in accordance with the Creative Commons Attribution Non Commercial (CC BY-NC 3.0) license, which permits others to distribute, remix, adapt, build upon this work non-commercially, and license their derivative works on different terms, provided the original work is properly cited and the use is non-commercial. See: http://creativecommons.org/licenses/by-nc/3.0/

\section{REFERENCES}

1 Lyons A, McNeill A, Chen $Y$, et al. Tobacco and tobacco branding in films popular in the UK 1989-2008. Thorax 2010;65:417-22.

2 Everett S, Schnuth RL, Tribble JL. Tobacco and alcohol use in top-grossing American films. J Community Health 1998;23:317-24.

3 Dalton M, Tickle JJ, Sargent JD, et al. The incidence and context of tobacco use in popular movies from 1988 to 1997. Prev Med 2002;34:516-23.

4 Mekemson C, Glik D, Titus K, et al. Tobacco use in popular movies during the past decade. Tob Control 2004;13:400-2.

5 Sargent J, Beach ML, Dalton MA, et al. Effect of seeing tobacco use in films on trying smoking among adolescents: cross sectional study. BMJ 2001;323:1394-7.

6 Dalton M, Sargent JD, Beach ML, et al. Effect of viewing smoking in movies on adolescent smoking initiation: a cohort study. Lancet 2003;362:281-5.

7 Sargent J, Beach ML, Adachi-Mejia AM, et al. Exposure to movie smoking: its relation to smoking initiation among US adolescents. Pediatrics 2005;116:1183-91.

8 U.S. Department of Health and Human Services. Preventing tobacco use among youth and young adults: a report of the Surgeon General. Rockville, MD: U.S. Department of Health and Human Services, 2012. http://www.surgeongeneral.gov/ library/preventing-youth-tobacco-use/full-report.pdf (accessed 14 Jun 2012).

9 Broadcasters' Audience Research Board (BARB). Television Ownership in Private Domestic Households 1956-2011. London 2011. http://www.webcitation.org/ query? url=http $\% 3 \mathrm{~A} \% 2 \mathrm{~F} \% 2 \mathrm{Fwww}$.barb.co.uk\%2Ffacts\%2FtvOwnershipPrivate $\%$ 3F s\%3D4\&date $=2011-10-07$ (accessed 1 Aug 2011).

10 Livingstone S, Bovill M. Young people, new media: report of the research project Children Young People and the Changing Media Environment. Research report. London: Department of Media and Communications, London School of Economics and Political Science, 1999. http://eprints.Ise.ac.uk/21177/1/Young_people_new_ media_\%28LSERO\%29.pdf (accessed 10 Nov 2011).

11 British Film Institute. Statistical Yearbook 2012. London: British Film Institute, 2012 http://www.bfi.org.uk/statisticalyearbook2012/ (accessed 1 Aug 2012).

12 McGee R, Ketchel J. Tobacco imagery on New Zealand television 2002-2004. Tob Control 2006;15:412-14

13 Christenson P, Henriksen L, Roberts DF. Substance use in popular prime-time television. Washington, DC: Office of National Drug Control Policy, 2000

14 Cullen J, Sokol NA, Slawek D, et al. Depictions of tobacco use in 2007 broadcast television programming popular among US youth. Arch Pediatr Adolesc Med 2011;165:147-51.

15 Hanewinkel R, Wiborg G. Smoking in contemporary German television programming. Int J Public Health 2007;52:308-12.

16 Hanewinkel R, Wiborg G. Smoking in a popular German television crime series 1985-2004. Prev Med 2008;46:596-8.

17 Kanda H, Okamura T, Turin TC, et al. Smoking scenes in popular Japanese serial television dramas: descriptive analysis during the same 3-month period in two consecutive years. Health Promot Int 2006;21:98-103.

18 Cumberbatch G, Gauntlett S. Smoking, alcohol, and drugs on television: a content analysis. London: Ofcom, 2005. http://www.webcitation.org/query?url=http $\% 3 \mathrm{~A} \%$ 2F\%2Fstakeholders.ofcom.org.uk\%2Fbinaries \%2Fresearch\%2Fradio-research\% 2Fsmoking.pdf\&date=2011-10-07 (accessed 10 Nov 2008).

19 The Tobacco Advertising and Promotions Act 2002. http://www.webcitation.org/ query?url=http $\% 3 \mathrm{~A} \% 2 \mathrm{~F} \% 2 \mathrm{Fwww}$.legislation.gov.uk\%2Fukpga $\% 2 \mathrm{~F} 2002 \% 2 \mathrm{~F} 36 \%$ 2Fcontents\&date $=2011-10-07$ (accessed 19 Oct 2008).

20 Ofcom. Ofcom. London 2011. http://www.ofcom.org.uk/ (accessed 3 Apr 2011)

21 Communications Act 2003. London: HMSO. http://www.webcitation.org/query? url=http \%3A\%2F\%2Fwww.legislation.gov.uk\%2Fukpga\%2F2003\%2F21\% 2Fcontents\&date $=2011-10-07$ (accessed 3 Apr 2009).

22 Ofcom. The Ofcom broadcasting code (Incorporating the cross-promotion code) London: Ofcom, 2009. http://www.webcitation.org/query?url=http $\% 3 \mathrm{~A} \% 2 \mathrm{~F} \%$ 2Fstakeholders.ofcom.org.uk\%2Fbinaries\%2Fbroadcast\%2Fcode09\%2Fbcode09. pdf\&date $=2011-10-07$ (accessed 21 Jul 2011) 
23 Ofcom. What is the watershed? London 2011. http://www.webcitation.org/query? url=http $\% 3 \mathrm{~A} \% 2 \mathrm{~F} \% 2 \mathrm{Fconsumers.ofcom}$.org.uk $\% 2 \mathrm{~F} 2011 \% 2 \mathrm{~F} 06 \%$

2Fwhat-is-the-watershed\%2F\&date=2011-10-07 (accessed 9 Sep 2011).

24 Broadcasters' Audience Research Board (BARB). Channel Viewing Share. London 2011. http://www.webcitation.org/query?url=http\%3A\%2F\%2Fwww.barb.co.uk\% 2Fgraph\%2FviewingShare\%3F_s\%3D4\&date=2011-10-07 (accessed 26 May 2011).

25 Hazan A, Lipton HL, Glantz SA. Popular films do not reflect current tobacco use. Am J Public Health 1994;84:998-1000.

26 Stockwell T, Glantz SA. Tobacco use is increasing in popular films. Tob Control 1997:6:282-4.

27 Madden P, Grube JW. The frequency and nature of alcohol and tobacco advertising in televised sports, 1990 through 1992. Am J Public Health 1994:84:297-9.

28 Zwarun L. Ten years and 1 master settlement agreement later: the nature and frequency of alcohol and tobacco promotion in televised sports, 2000 through 2002. Am J Public Health 2006;96:1492-7.

29 Broadcasters' Audience Research Board (BARB). BARB: Broadcasters Audience Research Board. London 2011. http://www.webcitation.org/query?url=http\%3A\%2F \%2Fwww.barb.co.uk\%2F\&date=2011-10-07 (accessed 2 Jul 2011).

30 Attentional. 2012. http://www.attentional.com/ (accessed 1 Feb 2010).

31 Broadcasters' Audience Research Board (BARB). Weekly Top 10 Programmes. London 2011. http://www.webcitation.org/query?url=http\%3A\%2F\%2Fwww.barb.co.uk\% 2Freport\%2Fweekly-viewing\%3F_s\%3D4\&date=2011-10-07 (accessed 26 Jul 2011).
32 Hazan A, Glantz SA. Current trends in tobacco use on prime-time fictional television. Am J Public Health 1995;85:116-17.

33 Viswanath K, Ackerson LK, Sorensen G, et al. Movies and TV influence tobacco use in India: findings from a national survey. PLoS One 2010;5:e11365.

34 Gutschoven K, Van den Bulck J. Television viewing and smoking volume in adolescent smokers: a cross-sectional study. Prev Med 2004;39:1093-8.

35 Gutschoven K, Van den Bulck J. Television viewing and age at smoking initiation: does a relationship exist between higher levels of television viewing and earlier onset of smoking? Nicotine Tob Res 2005;7:381-5.

36 Hancox R, Milne BJ, Poulton R. Association between child and adolescent television viewing and adult health: a longitudinal birth cohort study. Lancet 2004;364:257-62.

37 Gidwani P, Sobol A, DeJong W, et al. Television viewing and initiation of smoking among youth. Pediatrics 2002;110:505-8.

38 National Cancer Institute. The Role of the Media in Promoting and Reducing Tobacco Use. Tobacco Control Monograph No. 19. Bethesda, MD: U.S. Department of Health and Human Services, National Institutes of Health, National Cancer Institute. NIH Pub. No. 07-6242, June 2008.

39 Hastings G and Angus K. (2008). Forever Cool: The Influence of Smoking Imagery on Young People. London: British Medical Association Board of Science, July, 1-62.

40 World Health Organisation (WHO). Smoke-free movies: From evidence to action. Geneva: World Health Organisation, 2009: 1-29. 